\title{
Late diagnosis of nodular melanoma of the foot in a 74-year-old Brazilian man
}

\author{
VITORINO M. SANTOS ${ }^{1,2}$, CRISTINA T. LEAL ${ }^{1}$, \\ MARTHA J. M. VASCONCELLOS ${ }^{2}$
}

\begin{abstract}
The incidence and mortality of malignant melanoma is increasing. Its early diagnosis can contribute to a favorable prognosis. We report a 74-year-old black man with a dark brown mole in the right plantar area, that grew slowly in the last decade. A biopsy of the lesion revealed a nodular malignant melanoma. A wide excision of the tumor was performed 18 months ago, followed by chemotherapy for nine months. At admission, the patient was debilitated, and presented with numerous nodules in the lower limb and suprapubic area. Imaging studies disclosed chest and abdominal nodules. The patient died 13 days after admission.
\end{abstract}

(Rev Med Chile 2011; 139: 1481-1483).

Key words: Foot; Melanoma; Metastasis.

\section{Diagnóstico tardío de melanoma nodular del pie en un varón con 74 años}

Melanoma maligno constituye una importante preocupación debido al incremento de la incidencia y mortalidad. El diagnóstico precoz de esta malignidad puede contribuir para prognósticos favorables. Se describe el diagnóstico tardío de melanoma nodular del pie en un varón afro-brasileño con 74 años de edad. El propósito es aumentar el indice de sospecha acerca de esta infrecuente localización del tumor de la piel, y estimular a los médicos de cuidado primario para realizar examen minucioso del cuerpo entero, contribuyendo a la detección temprana de los cánceres de piel.

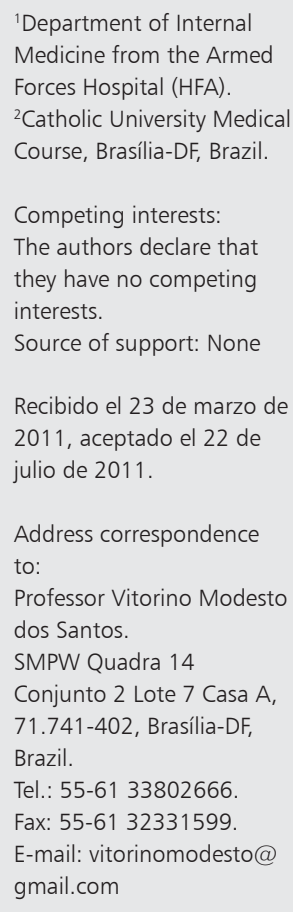

$\mathrm{R}$ ecently, malignant melanoma (MM) has become a subject of major interest due to an increasing incidence and high morbidity and mortality rates ${ }^{1-6}$. Although this tumor represents only $4-5 \%$ of the skin cancers, it is the main cause of death related to skin malignancies, due to late diagnosis and high potential of distant metastases. Foot and nail are uncommon sites (3-15\%), with poor prognosis and high lethality ${ }^{1-6}$. Worth of note, a study of 4,607 Hispanic Californians with $\mathrm{MM}$ showed thicker tumors, in a late stage at diagnosis, with metastases and poor outcomes ${ }^{4}$. In addition to the pattern of sun exposure, ethnic and genetic factors may play a role on the development of MM in population groups. ${ }^{7}$

Chilean population has a large proportion of descendants from Spanish settlers or immigrants from Spain. Alonso et al. studied the general features of 1,975 deaths by MM in Chile and found $44.5 \%$ of lower limb and hip location; $54 \%$ of the patients were men, and median age was 71 years ${ }^{1}$. Zemelman et al. reviewed 575 cases of MM in Chilean public hospitals and reported a high number of lesions on the extremities of male patients, including the soles. Interestingly, the predominant location of MM in men was similar to that often 


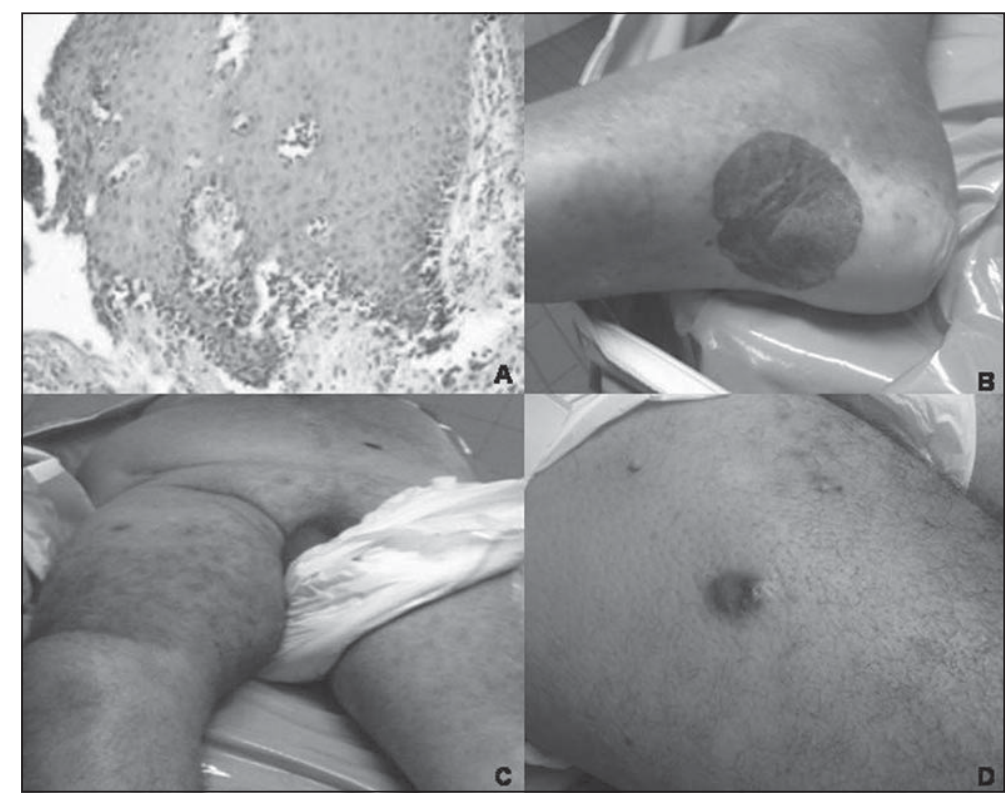

Figure 1. (A) Photomicrograph of the melanoma of the foot showing the intraepidermal component of the tumor cells producing melanin (H\&E, $\mathrm{x} 10)$. (B) Aspect of the plastic surgery reconstruction performed over the site of the excised melanoma. (C and D) Metastases of primary nodular melanoma of the right foot appearing as black macules, papules, and nodules with centripetal distribution on the lower limb and suprapubic area. observed in black people, with poorer prognosis and higher mortality rate than among women ${ }^{7}$.

We report the case of an Afro-Brazilian old man with late diagnosis of nodular MM on the plantar area, aiming to highlight the adverse consequences of late detection of this ominous tumor ${ }^{1}$. The role of thorough skin examination of the whole body is emphasized as the best tool for the early diagnosis of skin tumors.

\section{Case report}

A 74-year-old dark-skinned man had a dark brown mole on his right plantar area, with slow growing for more than a decade. In another Service, surgical biopsies were done 18 months ago, and two skin samples $(0.9 \times 0.2 \times 1.0 \mathrm{~cm}$ and 1.5 x $0.9 \times 0.2 \mathrm{~cm}$ ) were studied. The histopathology analysis disclosed an asymmetric and compound melanocytic lesion, with nodular configuration, exophytic and endophytic, with a thickness of $2.5 \mathrm{~mm}$ and epidermal ulceration. The tumor had a predominant epithelioid component with large cells showing high nucleus/cytoplasm ratio, nuclear irregularity and hyperchromatism, maturation defects and conspicuous atypia. The hypoderm was also infiltrated and maturation was not observed in the deeper zones. There was an accentuated lymphocyte infiltration permeated by melanophages, and the surgical borders were extensively involved by malignant cells (Figure 1A). Although the surface of the lesion was ulcerated, neither vascular nor perineural invasion was seen. The diagnosis of nodular MM with reticular dermal invasion (Clark IV) and vertical axis of 2.5 $\mathrm{cm}$ (Breslow III) was established. Wide excision of the tumor was performed, with local plastic reconstruction (Figure 1B). During nine months he was treated with adjuvant chemotherapy with interferon, further changed by cytotoxic chemotherapy with temozolomide $\left(200 \mathrm{mg} / \mathrm{m}^{2} /\right.$ day $)$.

On admission to our hospital, he was debilitated and had numerous brown black macules, papules, and nodules with centripetal distribution in the right lower limb and suprapubic area (Figure 1C and 1D). Enlarged lymph nodes were palpated on the right inguinal region. Complementary blood determinations showed anemia (hematocrit: $31.7 \%$ and hemoglobin: $10.8 \mathrm{~g} / \mathrm{dl}$ ), hypoalbuminemia $(2.2 \mathrm{~g} / \mathrm{dl})$, elevated levels of aminotransferases (AST: $150 \mathrm{U} / \mathrm{l}$ and ALT: $123 \mathrm{U} / \mathrm{l}$ ) as well as of bilirubin $(2.3 \mathrm{mg} / \mathrm{dl})$, in addition to blood urea nitrogen $(70 \mathrm{mg} / \mathrm{dl})$ and creatinine $(1.4$ $\mathrm{mg} / \mathrm{dl}$ ). Ultrasound and computed tomography imaging of the abdomen revealed hepatomegaly, splenomegaly, hepatic nodule $(1.2 \mathrm{~cm})$, splenic nodules and ascites. Thorax computed tomogra- 
phy showed a left lung nodule $(0.5 \mathrm{~cm})$ and right pleural effusion. Despite nutrition support and clinical care, his general condition progressively worsened, and death occurred 13 days after admission. Permission to perform an autopsy study could not be obtained.

\section{Discussion}

The relative rarity, frequent delay in diagnosis, and difficult assessment by A B C D E system and 7-point checklist contribute to frequent misdiagnosis $(25-66 \%)$ and bad outcomes of nodular MM arising on the foot ${ }^{2,3,5-8}$. The new acronym CUBED (Colored lesion, Uncertain diagnosis, Bleeding lesion, Enlargement of the lesion, Delay in healing of the lesion beyond 2 months) has been useful to obtain an earlier recognition of foot and nail $\mathrm{MM}^{2,3}$. Nodular melanoma is prevalent in older male patients, and appears with smaller diameter, more regular border and uniform color than superficial spreading melanoma; and ulceration is considered an indicative sign of tumor aggressiveness and poor prognosis ${ }^{8}$. MM often affects individuals with antecedent moles, dysplastic or congenital nevi, and lentigo maligna, and predisposing factors may be genetic, biological, ultraviolet radiation, and trauma. Clinical forms of MM include lentigo maligna, superficial spreading melanoma, nodular melanoma, and acral lentiginous melanoma. The diagnostic approach is based on anamnesis, physical examination and dermatoscopy, but a definitive diagnosis is established by histopathology findings. Pigmented MM should be differentiated from conditions like seborrheic keratosis, basal cell carcinoma, dermatofibroma, and thrombosed capillary angioma. Non-melanotic MM may mimic pyogenic granuloma and sarcoma. Surgery is the most effective treatment of MM in early stage, and lymphadenectomy may be needed. Treatment of late-stage melanoma includes chemotherapy, cryotherapy, drug combinations, radiotherapy, tumor injections, tumor-inhibiting chemical agents and vaccines.

The role of early diagnosis must be emphasized because MM is susceptible to cure if treated at an initial stage. Skin lesions suggesting MM should be assessed by a dermatologist before biopsy, because prompt diagnosis and due treatment avoids the tumor spreading.

\section{References}

1. Alonso FT, Garmendia ML, Bogado ME. Increased skin cancer mortality in Chile beyond the effect of ageing: temporal analysis 1990 to 2005. Acta Derm Venereol 2010; 90: 141-6.

2. Bristow IR, de Berker DA. Development of a practical guide for the early recognition for malignant melanoma of the foot and nail unit. J Foot Ankle Res 2010; 28:3-22. doi: 10.1186/1757-1146-3-22.

3. Bristow IR, de Berker DA, Acland KM, Turner RJ, Bowling J. Clinical guidelines for the recognition of melanoma of the foot and nail unit. J Foot Ankle Res 2010; 3:25. doi: 10.1186/1757-1146-3-25.

4. Pollitt RA, Clarke CA, Swetter SM, Peng DH, Zadnicks J, Cockburn M. The expanding melanoma burden in California hispanics. Cancer 2011; 117: 152-61.

5. Roh MR, Kim J, Chung KY. Treatment and outcomes of melanoma in acral location in Korean patients. Yonsei Med J 2010; 51: 562-8.

6. Schade VL, Roukis TS, Homann JF, Brown T. "The malignant wart": a review of primary nodular melanoma of the foot and report of two cases. J Foot Ankle Surg 2010; 49: 263-73.

7. Zemelman V, Roa J, Tagle SR, Valenzuela CY. Malignant melanoma in Chile: an unusual distribution of primary sites in men from low socioeconomic strata. Clin Exp Dermatol 2006; 31: 335-8.

8. Warycha MA, Christos PJ, Mazumdar M, Darvishian F, Shapiro RL, Berman RS, et al. Changes in the presentation of nodular and superficial spreading melanomas over 35 years. Cancer 2008; 113: 3341-8. 